\title{
ANALISIS KESULITAN SISWA DALAM MENYELESAIKAN MASALAH GEOMETRI DITINJAU DARI KEMAMPUAN MATEMATIKA SISWA
}

\author{
Vera Rosalina Bulu ${ }^{1 *}$, Taty R. Koroh ${ }^{2}$ \\ ${ }^{1}$ Universitas Citra Bangsa, Kupang, Indonesia, ${ }^{2}$ Universitas Nusa Cendana, Kupang, Indonesia \\ *Corresponding Author: $\otimes$ veraros0451@gmail.com
}

\begin{tabular}{l}
\hline Info Artikel \\
\hline Sejarah Artikel: \\
Diterima: $28 / 12 / 2021$ \\
Direvisi : 05/01/2021 \\
Disetujui:06/01/2021 \\
\hline Keywords: \\
Student Difficulties, \\
Problem Solving, \\
Geometry \\
\hline
\end{tabular}

Kata Kunci:

Kesulitan Siswa,

Pemecahan Masalah,

Geometri

\begin{abstract}
This research aims to describe the difficulty of students in solving mathematical problems of geometric materials in view of the student's mathematical abilities. Description of the student's difficulties can help the teacher as information to provide solutions in overcoming the difficulties of students in solving geometry problems. This research is descriptive qualitative research. This research was imposed on students of class VIII of State Junior High School I Amanuban Barat. The sample in the study was 3 students with high, moderate and low ability. Samples are taken using purposive sampling techniques. Data retrieval techniques use observations, interviews and geometric material troubleshooting tests. Data analysis techniques use qualitative data analysis. The results showed that highly capable students have difficulty in re-examining the results of problem solving, students are having difficulty in determining the strategy to be used, using those strategies to solve problems and re-examine the results of solving the problem. Furthermore, low-skilled students have difficulties ranging from understanding problems, determining settlement strategies, using settlement strategies and re-examining the solving of mathematical problems. This is because learners do not understand the concept of geometry, are not used to practicing problem solving problems that result in students not having strategies in solving mathematical problems encountered. Furthermore, the advice that can be given is that teachers need to map the difficulty of solving problems in each existing material so as to help teachers and students in overcoming difficulties solving math problems.
\end{abstract}

\begin{abstract}
Abstrak. Penelitian ini bertujuan untuk mendeskripsikan kesulitan siswa dalam menyelesaikan masalah matematika materi geometri ditinjau dari kemampuan matematika siswa. Deskripsi mengenai kesulitan siswa tersebut dapat membantu guru sebagai informasi untuk memberikan solusi dalam mengatasi kesulitan siswa dalam menyelesaikan masalah geometri. Penelitian ini merupakan penelitian kualitatif deskriptif. Penelitian ini dikenakan pada siswa kelas VIII-A SMP Negeri I Amanuban Barat. Sampel dalam penelitian ini yaitu 3 siswa dengan kemampuan tinggi, sedang dan rendah. Sampel diambil menggunanan teknik purposive sampling. Teknik pengambilan data menggunakan observasi, wawancara dan tes pemecahan masalah materi geometri. Teknik analisis data menggunakan analisis data kualitatif. Hasil penelitian menunjukan bahwa siswa berkemampuan tinggi kesulitan dalam memeriksa kembali hasil penyelesaian masalah, siswa berkemampuan sedang mengalami kesulitan dalam menentukan strategi yang akan digunakan, menggunakan strategi tersebut untuk menyelesaikan masalah dan memeriksa kembali hasil penyelesaian masalah tersebut. Selanjutnya siswa berkemampuan rendah memiliki kesulitan mulai dari memahami masalah, menentukan strategi penyelesaian, menggunakan strategi penyelesaian dan memeriksa kembali penyelesaian masalah matematika. Hal ini dikarenakan peserta didik kurang memahami konsep geometri, tidak terbiasa berlatih soal pemecahan masalah yang mengakibatkan siswa tidak memiliki strategi - strategi dalam menyelesaikan masalah matematika yang ditemui. Selanjutnya, saran yang dapat diberikan yaitu guru perlu memetakan kesulitan menyelesaikan masalah pada setiap materi yang ada sehingga membantu guru dan siswa dalam mengatasi kesulitan menyelesaikan masalah matematika.
\end{abstract}

How to Cite: Bulu, V. R., \& Koroh, T. R. (2022). ANALISIS KESULITAN SISWA DALAM MENYELESAIKAN MASALAH GEOMETRI DITINJAU DARI KEMAMPUAN MATEMATIKA SISWA. Prima Magistra: Jurnal Ilmiah Kependidikan, 3(1), 139-149. https://doi.org/10.37478/jpm.v3i1.1514

Alamat korespondensi:

Jl. Manafe No.17, Kayu Putih, Kec. Oebobo, Kota Kupang, Nusa Tenggara Tim. 85111

(Q) veraros0451@gmail.com

\section{Penerbit:}

Program Studi PGSD Universitas Flores.

ه primagistrauniflor@gmail.com 


\section{PENDAHULUAN}

Salah satu keterampilan abad 21 yang perlu dimiliki oleh peserta didik yaitu kemampuan pemecahan masalah. NCTM (2000) juga memuat salah satu keterampilan yang perlu dimiliki oleh peserta didik yaitu keterampilan pemecahan masalah. Oleh sebab itu, pembelajaran matematika di semua jenjang pendidikan menjadikan pemecahan masalah menjadi fokus utama dalam pembelajaran matematika (Hidayat \& Sariningsih, 2018; Mawaddah \& Anisah, 2015; Widjajanti, 2009).

Pemecahan masalah suatu prosedur untuk menyelesaikan masalah (Widjajanti, 2009). Dikatakan lebih lanjut oleh Hidayat \& Sariningsih (2018) yang menyatakan bahwa pemecahan masalah memuat empat langkah penyelesaian yaitu memahami masalah, merencanakan penyelesaian masalah, menyelesaikan masalah dan melakukan pengecekan kembali. Hertiavi et al. (2010) menyatakan bahwa pemecahan masalah bermanfaat bagi siswa untuk memberi makna terhadap pengetahuan yang dimiliki. Selain itu dikatakan oleh Ayubi et al. (2018, Hadi \& Radiyatul (2014), serta Nasir, 2016) bahwa pemecahan masalah membantu peserta didik untuk menerapkan pengetahuan dan pengalaman yang dipelajari sebelumnya untuk lebih kritis dan kreatif dalam menyelesaikan masalah dalam kehidupan sehari - hari.

Fakta yang ditemui menyatakan bahwa kemampuan pemecahan masalah peserta didik di Indonesia masih rendah. Berdasarkan hasil PISA 2018 menyatakan bahwa skor rata - rata siswa Indonesia dalam menyelesaikan masalah matematika berada pada posisi yang lebih rendah yaitu 379 dari skor rata - rata OECD yaitu 487. Tambahan lagi, dinyatakan bahwa kemampuan menyelesaikan masalah matematika masih dalam level 2 dari 6 level. Hal ini peserta didik hanya mampu menyelesaikan masalah matematika dengan mengambil referensi dari satu sumber dan hanya dapat menyelesaikan masalah dengan satu cara penyelesaian. Padahal, salah satu indikator dari pemecahan masalah yaitu mampu menyelesaikan masalah dengan lebih dari satu cara penyelesaian.
Lebih lanjut, berdasarkan hasil observasi dan wawancara yang dilakukan terhadap peserta didik kelas VIII-A dan guru matematika di SMP Negeri I Amanuban Barat ditemukan bahwa peserta didik memiliki nilai rata - rata matematika yang rendah untuk materi Geometri. Dari jumlah siswa yaitu 22 orang, sekitar $75 \%$ memiliki nilai di bawah KKM yaitu 75. Dikatakan oleh guru bahwa soal yang diberikan beberapa diantaranya merupakan soal pemecahan masalah karena merupakan tuntuntan untuk mengintegrasikan pemecahan masalah dalam pemebelajaran matematika. Hal ini mengindikasikan bahwa sebagian besar peserta didik kelas VIII-A SMP Negeri I Amanuban Barat memiliki kesulitan dalam menyelesaikan masalah matematika materi geometri.

Fakta tersebut menunjukan bahwa siswa masih mengalami kesulitan dalam menyelesaikan masalah matematika. Dilansir dari beberapa sumber, ditemui beberapa kesulitan peserta didik dalam menyelesaikan masalah matematika, diantaranya penelitian yang dilakukan oleh Jamal (2014), Mirati (2015), dan Utari et al. (2019) yang menyatakan bahwa kesulitan peserta didik dalam menyelesaikan masalah yaitu kurang memahami konsep, kurang memahami informasi soal, kurang memahami strategi yang digunakan untuk menyelesaikan soal dan tidak terbiasa melakukan pemeriksaan kembali terhadap hasil kerja.

Lebih lanjut dikatakan oleh Novferma (2016), kesulitan tersebut dikarenakan siswa tidak terbiasa mengerjakan soal pemecahan masalah sehingga tidak terbiasa memahami soal dan strategi - strategi yang bisa digunakan dalam menyelesaikan masalah tertentu. Faktor lainnya yang mempengaruhi kesulitan menyelesaikan masalah matematika yaitu peserta didik sering tergesa - gesa, cemas dan kurang teliti dalam menyelesaikan soal pemecahan masalah. Cara untuk mengurangi kesulitan peserta didik dalam menyelesaikan masalah yaitu dengan adanya bimbingan dari guru (Novferma, 2016). Namun, bimbingan guru tersebut perlu didasari dengan pengetahuan mengenai kesulitan peserta didik dalam menyelesaikan masalah matematika. 
Berdasarkan uraian tersebut, maka perlu dilakukan analisis kesulitan peserta didik kelas VIII-A dalam menyelesaikan masalah matematika pada materi geometri. Penelitian ini bertujuan untuk mendeskripsikan kesulitan peserta didik kelas VIII-A SMP Negeri I Amanuban Barat dalam menyelesaikan masalh matematika ditinjau dari kemampuan matematika siswa. Adapun penelitian ini bermanfaat untuk membantu guru memahami kesulitan menyelesaikan masalah matematika oleh peserta didik sehingga dapat di berikan solusi terkait hal tersebut.

\section{METODE PENELITIAN}

Penelitian ini menggunakan jenis penelitian kualitatif deskriptif. Prosedur penelitian ini meliputi tiga tahap yaitu tahap persiapan, tahap pelaksanaan dan tahap analisis data dan penarikan kesimpulan. Tahap persiapan yaitu menentukan subjek penelitian dan mempersiapkan instrumen penelitian. Selanjutnya, pada tahap pelaksanaan siswa diberikan masalah bangun ruang kubus dan balok untuk dikerjakan setelah itu dilakukan wawancara untuk mengkonfirmasi kesulitan siswa dalam menyelesaikan masalah bangun ruang kubus dan balok berdasarkan hasil pekerjaan siswa. Lebih lanjut pada tahap analisis data yaitu data dianalisis dan ditarik kesimpulan berdasarkan hasil analisis tersebut.

Penelitian ini dikenakan pada siswa kelas VIII-A semester ganjil 2021/ 2022 bertempat di SMP Negeri I Amanuban Barat. Teknik pengambilan sampel dalam penelitian ini yaitu purposive sampling yaitu pengambilan sampel berdasarkan tujuan/ pertimbangan tertentu. Adapun pertimbangan dalam pengambilan sampel yaitu (1) Sampel sudah/ sedang mendapatkan materi geometri, (2) sampel dapat berkomunikasi lisan dan tulisan dengan baik. Pemilihan sampel berdasarkan dua tujuan ini dimaksudkan agar peneliti dapat mengambil data secara objektif dan lancar. Berdasarkan teknik pengambilan sampel tersebut dipilih 3 siswa untuk dijadikan sampel dalam penelitian ini.

Selanjutnya, teknik pengumpulan data menggunakan observasi, tes dan wawancara tidak terstruktur sehingga instrumen yang digunakan dalam penelitian ini yaitu pedoman observasi, pedoman wawancara dan soal cerita geometri. Penentuan subjek penelitian dilakukan dengan metode wawancara dengan guru matematika kelas VIII-A serta perhitungan nilai rata-rata dan standar deviasi untuk menentukan kriteria pengelompokan siswa berkemampuan tinggi, sedang dan rendah.

Menurut Somakim dalam (Purnamasari \& Setiawan, 2019) menyatakan bahwa kriteria pengelompokan siswa berkemampuan tinggi, sedang dan rendah siswa berdasarkan skor rata - rata dan simpangan baku sebagai berikut.

Siswa Kemampuan Tinggi:

$\mathrm{KAM} \geq \bar{x}+\mathrm{SB}$

Siswa Kemampuan Sedang:

$\bar{x}-S B \leq K A M \leq \bar{x}+S B$

Siswa Kemampuan Rendah:

$\mathrm{KAM} \geq \bar{x}-\mathrm{SB}$

Berdasarkan rumus tersebut dibuatlah pengelompokkan siswa berdasarkan kemampuan matematika yaitu

Siswa berkemampuan Tinggi:

$\mathrm{KAM} \geq 63.18+13.58$

$\mathrm{KAM} \geq 76.76$

Siswa Berkemampuan Sedang:

$63.18-13.58 \leq \mathrm{KAM} \leq 63.18+13.58$

$49.59 \leq \mathrm{KAM} \leq 76.76$

Siswa berkemampuan Rendah:

$\mathrm{KAM} \leq 63.18-13.58$

$\mathrm{KAM} \leq 49.59$

Selanjutnya, dilakukan wawancara untuk menentukan subjek dengan komunikasi lisan yang baik sehingga dapat memberikan informasi dengan lancer kepada peneliti. Berdasarkan hasil wawancara dan perhitungan nilai tersebut dipilih subjek penelitian sebanyak 3 orang yaitu 1 subjek berkemampuan tinggi, sedang dan rendah. Adapun subjek penelitian tersebut dapat dilihat pada tabel berikut.

Tabel 1. Subjek Penelitian

\begin{tabular}{cc}
\hline $\begin{array}{c}\text { Inisial subjek } \\
\text { penelitian }\end{array}$ & Kemampuan \\
\hline JN & Tinggi \\
\hline KP & Sedang \\
\hline AB & Rendah \\
\hline
\end{tabular}


Selanjutnya dilakukan pembuatan instrumen penelitian yaitu pedoman observasi, tes pemecahan masalah bangun ruang kubus dan balok serta pedoman wawancara. Pembuatan tes pemecahan masalah bangun ruang kubus dan balok di awali dengan pembuatan kisi-kisi soal tes termasuk didalammnya yaitu penentuan $\mathrm{KD}$ dan indikator untuk membuat soal pemecahan masalah untuk bangun ruang kubus dan balok.

Berikut instrument tes pemecahan masalah materi kubus dan balok yang akan diberikan kepada siswa kelas VIII-A SMP Negeri I Amanuban Barat berdasarkan tingkat kemampuan matematika.

1. Endang dan Budi memiliki kotak pensil berbentuk kubus. Panjang sisi kotak pensil Endang adalah $14 \mathrm{~cm}$, sedangkan milik Budi panjang sisinya adalah $18 \mathrm{~cm}$. Hitunglah selisih volume kotak pensil milik endang dan Budi!

2. Perhatikan gambar berikut

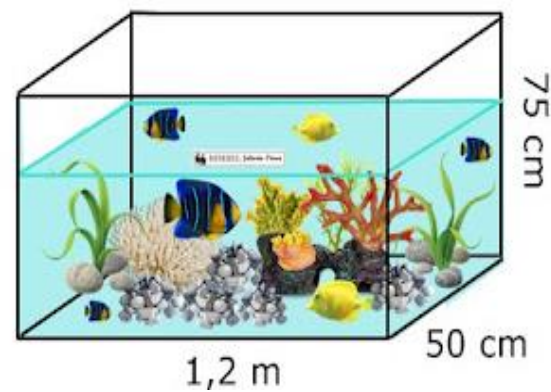

Jika volume air dalam akuarium tersebut adalah 2/3 dari volume akuarium, maka volume air dalam akuarium adalah...... liter

Selanjutnya dilakukan validasi ahli oleh validator ahli matematika oleh 2 dosen matematika dan 1 guru matematika SMP Negeri I Amanuban Barat. Berdasarkan hasil validasi dari 3 validator ahli, instrumen tes pemecahan masalah matematika dapat digunakan tanpa revisi.

Selanjutnya terkait dengan pedoman wawancara, digunakan indikator berdasarkan 4 tahap pemecahan masalah Polya. Indikator tersebut dapat dilihat pada tabel berikut.
Tabel 2. Indikator Kesulitan Belajar Berdasarkan Langkah Pemecahan Masalah Polya

\begin{tabular}{|c|c|}
\hline $\begin{array}{c}\text { Langkah } \\
\text { Pemecahan } \\
\text { Masalah Polya }\end{array}$ & Indikator Kesulitan Belajar \\
\hline $\begin{array}{l}\text { Langkah } 1 . \\
\text { Memahami } \\
\text { Masalah }\end{array}$ & $\begin{array}{l}\text { 1. Siswa tidak menuliskan apa } \\
\text { yang diketahui dan } \\
\text { ditanyakan. }\end{array}$ \\
\hline & $\begin{array}{l}\text { 2. Siswa belum lengkap } \\
\text { menuliskan apa yang } \\
\text { diketahui dan ditanyakan. }\end{array}$ \\
\hline
\end{tabular}

3. Siswa menuliskan apa yang diketahui dan ditanyakan namun salah.

\begin{tabular}{lrlr}
\hline Langkah & 2. & 1. & Siswa tidak mampu \\
Membuat & & $\begin{array}{l}\text { menentukan strategi dalam } \\
\text { menyelesaikan masalah } \\
\text { perencanaan }\end{array}$ \\
& 2. & $\begin{array}{l}\text { Siswa mampu menentukan } \\
\text { strategi r dalam } \\
\text { menyelesaikan masalah } \\
\text { matematika namun tidak } \\
\end{array}$ \\
& & \\
& lengkap.
\end{tabular}

3. Siswa menentukan strategi dalam menyelesaikan masalah namun salah

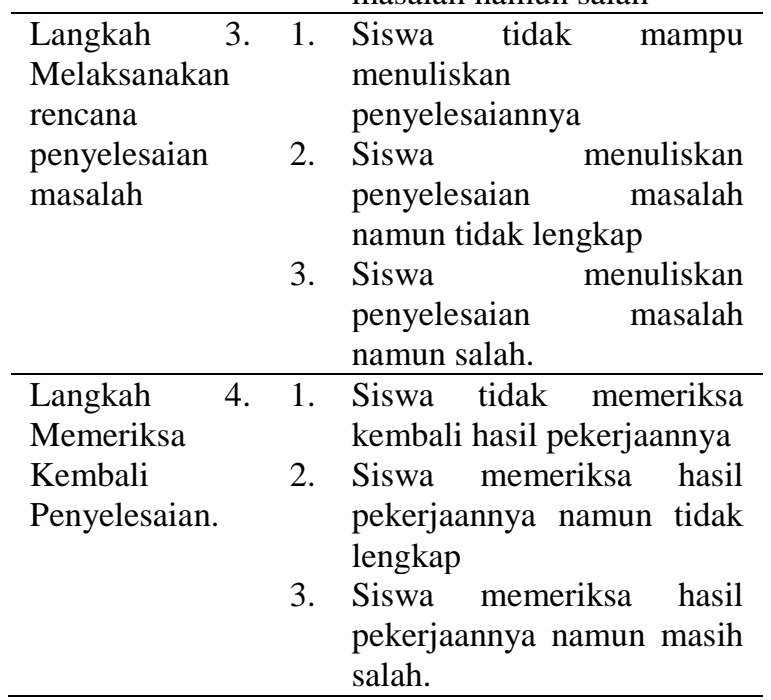

\section{HASIL DAN PEMBAHASAN}

Berdasarkan hasil tes dan wawancara yang dilakukan terhadap 3 subjek penelitian. Didapatkan data kesulitan siswa dalam memecahkan masalah matematika materi bangun ruang kubus dan balok sebagai berikut.

\section{Kesulitan subjek berkemampuan tinggi}

Berikut hasil kerja subjek JN untuk masalah 1 dan 2. 


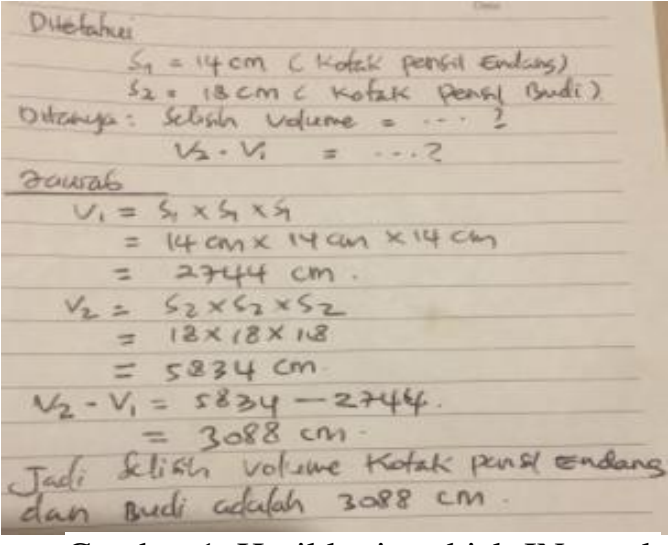

Gambar 1. Hasil kerja subjek JN untuk masalah 1

Berdasarkan gambar 1. dapat dilihat bahwa subjek JN dapat menuliskan hal - hal yang diketahui dan ditanyakan dari soal tersebut dengan baik. Selanjutnya terlihat bahwa subjek dapat menentukan strategi untuk menyelesaikan masalah tersebut yaitu mencari masing - masing volume kotak pensil. Namun pada tahap penyelesaian masalah menggunakan strategi tersebut subjek tidak dapat mengerjakan dengan benar. Hal ini terlihat pada satuan yang digunakan yaitu $\mathrm{cm}$, padahal seharusnya $\mathrm{cm}^{3}$. Selain itu pada volume kedua subjek JN melakukan salah perhitungan yaitu yang seharusnya hasilnya yaitu $5832 \mathrm{~cm}^{3}$ namun ditulis $5834 \mathrm{~cm}$. Hal tersebut berdampak subjek tidak dapat menarik kesimpulan yang benar untuk penyelesaian masalah tersebut dan juga subjek tidak memeriksa kembali kebenaran penyelesaian masalah tersebut. Selanjutnya, hasi kerja subjek JN untuk masalah 2.

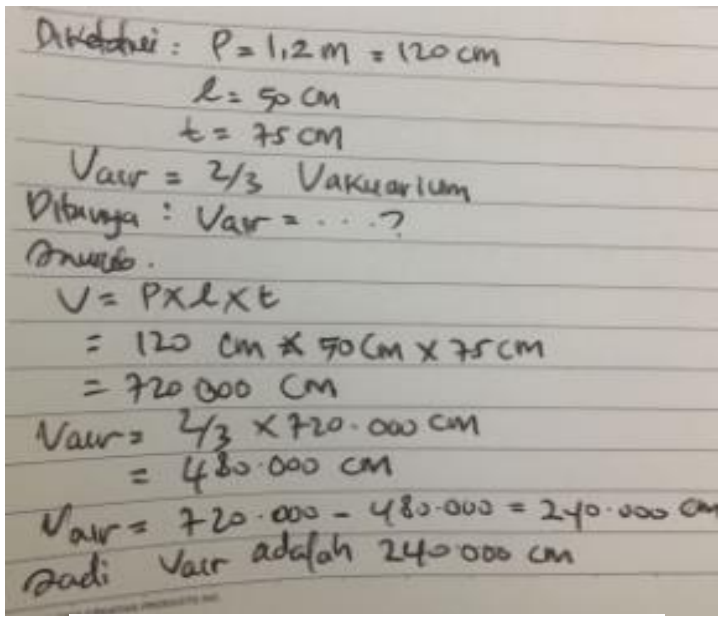

Gambar 2. Hasil kerja subjek JN untuk masalah 2
Berdasarkan gambar 2. dapat dilihat bahwa subjek JN dapat memahami masalah dengan baik. Hal ini terlihat bahwa subjek JN dapat menulis dengan benar informasi yaitu panjang $(p)$, lebar $(l)$ dan tinggi $(t)$ akuarium serta volume air dalam akuarium. Selanjutnya, subjek JN juga mengetahui strategi yang digunakan yaitu mencari volume akuarium, setelah itu, mencari volume air. Namun dalam penyelesaian masalah, subjek JN tidak dapat menyelesaikan masalah dengan benar. Subjek menuliskan volume akuarium yaitu 720.000 cm padahal seharusnya $720.000 \mathrm{~cm}^{3}$. Begitu pula dengan volume air, setelah mengalikan $2 / 3$ dengan volume akuarium, subjek JN kemudian mengurangi volume akuarium dengan hasil kali tersebut. Padahal seharusnya tidak perlu mengalikan. Hal ini membuat hasilnya menjadi tidak benar. Selanjutnya, subjek JN juga tidak dapatb menarik kesimpulan dengan benar dan tidak memeriksa kembali hasil kerjanya.

Selanjutnya dilakukan wawancara dengan subjek JN untuk mengkonfirmasi kembali hasil kerja subjek JN untuk masalah 1 dan 2 .

$\mathrm{P} \quad$ : Selamat pagi dek.

JN : Pagi kak.

P : Saya mau konfirmasi terkait dengan hasil pekerjaan adik untuk masalah 1 dan 2 .

JN :Iya kak

P :Pada masalah 1, apa yang diketahui dan ditanyakan dari soal tersebut.

JN : Panjang sisi kotak pensil berbentuk kubus Endang dan Budi. $\mathrm{S}_{1}=14 \mathrm{~cm}$ dan $\mathrm{S}_{2}=18$ $\mathrm{cm}$. Selanjutnya yang ditanyakan yaitu selisih volume dari kedua kotak pensil tersebut.

P : oiya baik. Kira2 adik mau gunakan strategi apa?

JN : Saya cari dulu volume kotak pertama dan volume kotak kedua setelah itu dicari selisihnya.

$\mathrm{P} \quad$ : Pada hasil kerja satuannya, cm ya?

JN : Iya kak. Cm.

$\mathrm{P} \quad$ : Yakin? Apa tidak mau diperiksa lagi?

JN : Iya kak. Cukup kak, saya rasa sudah benar kak.

P : Volume kotak pertama dan kedua, hasilnya sudah benar ya? 2744 dan 5834

JN : Saya rasa sudah benar kak

$\mathrm{P} \quad$ : Oke baik. Kita lanjut masalah kedua ya.

JN : Baik kak.

$\mathrm{P} \quad$ : Pada masalah kedua yang diketahui dan 
ditanyakan apa saja?

JN : yang diketahui Panjang, lebar dan tinggi akuarium serta volume air dalam akurium yaitu 2/3 dari volume akuarium sedangkan yang ditanyakan yaitu volume air.

$\mathrm{P}$ : strategi apa yang digunakan dalam mengerjakan masalah tersebut?

JN : Pertama - tama mencari volume akuarium dengan rumus $p x l x t$ setelah itu barulah dicari volume air dalam akuarium tersebut.

$\mathrm{P} \quad$ : Kenapa gunakan rumus tersebut?

JN : Karena akuarium tersebut berbentuk kubus kak. Sehingga saya gunakan volume kubus.

$\mathrm{P} \quad$ : volumenya dalam satuan $\mathrm{cm}$ ya?

JN : Iya kak.

$\mathrm{P}$ : Setelah dicari volume akuarium, kamu mencari volume air, setelah itu volume akuarium dikurangi volume air. Sudah yakin dengan jawaban ini? Kenapa harus mengurangi lagi volume akuarium dan volume air?

JN : Iya kak, karena yang diketahui volume akuarium maka perlu kita kurangi lagi volume akuarium dan volume air.

$\mathrm{P} \quad$ : Kamu sudah yakin dengan jawabannya? Tidak mau diperiksa kembali?

JN : Yakin kak.

P : Oke baik. Saya rasa cukup dek. Trimakasih untuk jawabannya.

JN : Sama sama kak.

Berdasarkan hasil kerja tersebut dapat disimpulkan bahwa bahwa pada tahap memahami masalah, terlihat subjek JN mampu memahami masalah dengan baik. Berdasarkan hasil pekerjaan tersebut, subjek JN dapat menyebutkan hal - hal yang diketahui dan ditanyakan dengan benar. Hal ini memperlihatkan bahwa subjek berkemampuan tinggi tidak mengalami kesulitan dalam memahami masalah. Selanjutnya, pada tahap membuat perencanaan, subjek JN dapat menentukan strategi yang digunakan untuk menyelesaikan masalah 1 dan masalah 2. Hal ini memperlihatkan subjek berkemampuan tinggi tidak mengalami kesulitan dalam membuat perencanaan masalah. Pada tahap melaksanakan rencana, subjek JN belum dapat melaksanakan rencana sesuai dengan perencanaan yang telah dibuat. Terlihat subjek JN dapat menyelesaikan masalah tersebut namun masih salah. Lebih lanjut, pada tahap memeriksa kembali, subjek JN mampu memeriksa kembali namun masih belum dapat memeriksa jawaban dengan benar dan melihat kesalahan pengerjaan soal pada tahap sebelumnya. Hal ini menunjukan subjek JN mengalami kesulitan pada tahap memeriksa kembali.

2. Kesulitan siswa berkemampuan sedang Berikut hasil kerja subjek KP dapat dilihat pada gambar berikut.

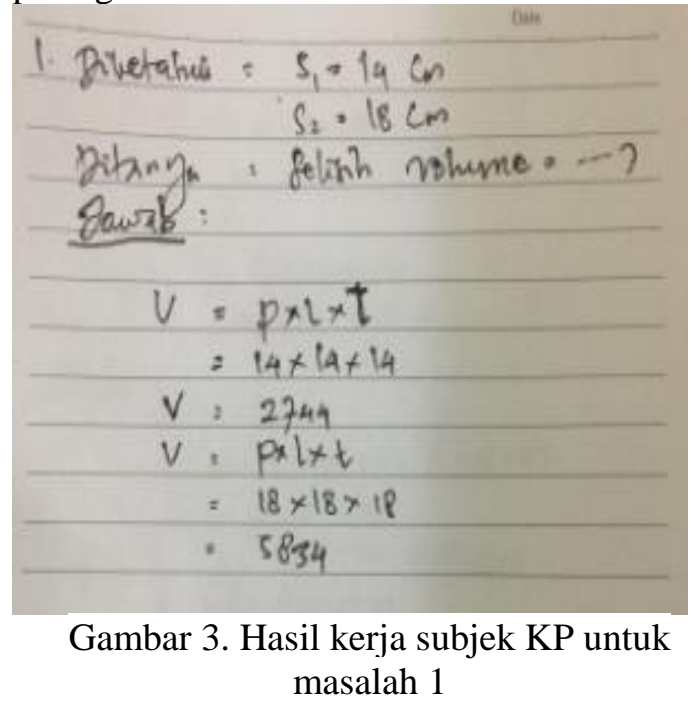

Berdasarkan hasil kerja subjek KP untuk masalah 1, didapatkan bahwa subjek KP dapat memahami dengan baik masalah yang diberikan. Hal ini terlihat subjek KP dapat menentukan Panjang sisi pertama $\left(\mathrm{S}_{1}\right)$ yaitu $14 \mathrm{~cm}$ dan panjang sisi kotak kedua $\left(\mathrm{S}_{2}\right)$ yaitu $18 \mathrm{~cm}$. Subjek KP juga dapat mengetahui yang ditanyakan dari masalah tersebut. Namun subjek KP terlihat mengalami kesulitan dalam menentukan strategi yang digunakan dimana subjek KP menulis rumus volume balok untuk mencari volume dari kotak pensil tesebut. Subjek KP mengira bahwa rumus volume kubus yaitu $p x l x t$ padahal seharusnya $s x s x s$. Dalam hasil kerja subjek KP juga tidak menentukan satuan dari volume dan melakukan salah perhitungan pada volume kedua. Subjek KP menulis 5834 padahal seharusnya 5832. Selanjutnya, subjek KP juga tidak menentukan Langkah selanjutnya setelah mendapatkan kedua volume dari kotak pensil tersebut, padahal seharusnya Langkah selanjutnya yaitu mencari selisih kedua volume tersebut. Selanjutnya, hasil kerja subjek KP untuk masalah kedua dapat dilihat pada gambar berikut. 


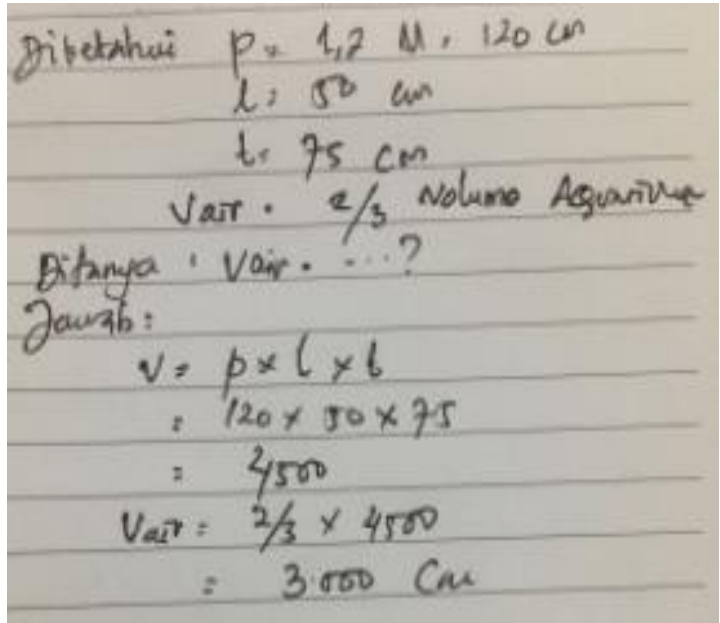

Gambar 4. Hasil kerja subjek KP untuk masalah 2

Berdasarkan hasik kerja subjek KP pada masalah 2 didapatkan bahwa subjek dapat mengetahui informasi dengan baik. Hal ini ditunjukan dari hasil kerjanya dimana subjek $\mathrm{KP}$ menulis panjang $(p)$, lebar $(l)$ dan tinggi (t) dengan benar. Subjek KP juga menulis volume air yaitu sama dengan volume akuarium. Selanjutnya subjek menentukan strategi yaitu mencari volume akuarium terlebih dahulu, namun dalam penyelesaian masalah subjek KP melakukan salah perhitungan, dimana ketika mengalikan panjang, lebar dan tinggi hasil yang diperoleh yaitu 4500 padahal seharusnya 450.000 , sehingga hal ini juga berdampak pada kesalahan mencari volume air dalam akuarium tersebut. Namun subjek tidak menyadari kesalahan tersebut.

Selanjutnya dilakukan wawancara dengan subjek KP untuk mengkonfirmasi kembali hasil kerja subjek KP untuk masalah 1 dan 2.

$\mathrm{P} \quad$ : Selamat pagi dek.

KP : Selamat pagi juga kak.

$\mathrm{P}$ : Mohon maaf mengganggu waktunya, Saya mau konfirmasi terkait dengan hasil pekerjaan dek untuk masalah 1 dan 2 .

KP :Iya kak, tidak apa apa kak.

$\mathrm{P}$ :Pada masalah 1, apa yang diketahui dan ditanyakan dari soal tersebut.

KP : Panjang sisi kotak pensil berbentuk kubus Endang dan Budi. $S_{1}=14 \mathrm{~cm}$ dan $S_{2}=18$ $\mathrm{cm}$. Selanjutnya yang ditanyakan yaitu selisih volume dari kedua kotak pensil tersebut.

P : oiya baik. Kira2 adik mau gunakan strategi apa?

KP : Saya cari volume kotak pertama dan volume kotak kedua dengan rumus $\mathrm{V}=p x$

lxt.

$\mathrm{P} \quad$ : Kenapa strateginya seperti itu?

KP : karena yang ditanyakan volume jadi bisa gunakan rumus tersebut untuk mencari volumenya.

$\mathrm{P} \quad$ : Yakin? Apa tidak mau diperiksa lagi?

KP : Iya kak. saya rasa sudah benar kak. Karena memang untuk mencari volume kita biasanya gunakan rumus tersebut.

P : Volume kotak pertama dan kedua, hasilnya sudah benar ya? 2744 dan 5834

KP : Saya rasa sudah benar kak.

$\mathrm{P} \quad$ : Oke baik. Apa tidak gunakan satuannya? Selanjutnya apa lagi yang perlu dicari dek?

KP : oiya kak seharusnya satuannya $\mathrm{cm}$, tadi lupa menulisnya. Saya tidak tau lagi caranya kak. .

P : Oiya baik dek. Makasih, kita lanjut ke masalah kedua ya,

KP : Baik kak, silahkan.

$\mathrm{P} \quad$ : Pada masalah kedua yang diketahui dan ditanyakan apa saja?

KP : yang diketahui Panjang, lebar dan tinggi akuarium serta volume air dalam akurium yaitu $2 / 3$ dari volume akuarium sedangkan yang ditanyakan yaitu volume air.

P : strategi apa yang digunakan dalam mengerjakan masalah tersebut?

KP : Kita mencari volume akuarium dengan rumus $p \times l x t$ setelah itu barulah dicari volume air dalam akuarium tersebut.

P :Oke baik. Saya melihat hasil kalinya yaitu 4500, apa sudah benar? Dan apa satuannya dek?

KP : Iya benar kak. Satuannya cm kak. Tapi saya lupa menulisnya kak.

$\mathrm{P} \quad$ : oke baik.

KP : Iya kak.

$\mathrm{P} \quad$ : Setelah dicari volume akuarium, kamu mencari volume air ya, hasilnya yang saya lihat yaitu $3000 \mathrm{~cm}$. sudah yakin jawabannya?

KP : Iya kak, benar kak, jawabannya seperti itu kak.

P : Oke baik. Makasih dek. Saya rasa cukup dek.

KP : Baik kak. Sama sama kak.

Pada tahap memahami masalah, terlihat subjek KP mampu memahami masalah dengan baik. Berdasarkan hasil pekerjaan tersebut, subjek KP dapat menyebutkan hal hal yang diketahui dan ditanyakan dengan benar. Hal ini memperlihatkan bahwa subjek berkemampuan sedang tidak mengalami kesulitan dalam memahami masalah. 
Selanjutnya, pada tahap membuat perencanaan, subjek KP tidak dapat menentukan strategi yang digunakan untuk menyelesaikan masalah 1 dan masalah 2 . Hal ini memperlihatkan subjek berkemampuan sedang mengalami kesulitan dalam membuat perencanaan masalah. Pada tahap melaksanakan rencana, subjek KP belum dapat menyelesaikan masalah sesuai dengan perencanaan yang telah dibuat. Terlihat subjek KP dapat menyelesaikan masalah tersebut namun masih salah. Lebih lanjut, pada tahap memeriksa kembali, subjek KP mampu memeriksa kembali namun masih belum dapat memeriksa jawaban dengan benar dan melihat kesalahan pengerjaan soal pada tahap sebelumnya. Hal ini menunjukan subjek KP mengalami kesulitan pada tahap memeriksa kembali.

\section{Kesulitan siswa berkemampuan rendah}

Berikut hasil kerja subjek $\mathrm{AB}$ dapat dilihat pada gambar berikut.

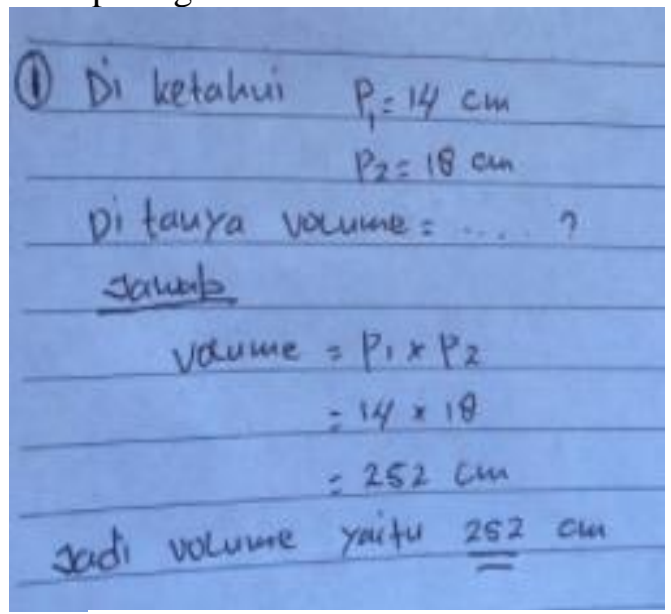

Gambar 5. Hasil kerja subjek AB untuk masalah 1

Berdasarkan hasil kerja subjek $\mathrm{AB}$, didapatkan bahwa subjek AB tidak dapat memahami informasi dengan benar. Hal ini terlihat dari hasil kerjanya dimana subjek AB menulis yang diketahui yaitu $\mathrm{P}_{1}=14 \mathrm{~cm}$ dan $\mathrm{P}_{2}=18 \mathrm{~cm}$ padahal seharusnya simbol matematika yang diketahui yaitu $S_{1}=14 \mathrm{~cm}$ dan $S_{2}=18 \mathrm{~cm}$. Selanjutnya, subjek $A B$ juga tidak dapat menyebutkan hal yang ditanyakan dengan benar, dimana subjek AB menyebutkan bahwa yang ditanyakan adalah volume padahal seharusnya selisih volume dari kedua kotak pensil. Lebih lanjut, terkait dengan strategi yang digunakan subjek AB tidak mampu menyebutkan dengan benar strategi yang digunakan. Subjek AB menyebutkan bahwa volume didapatkan dari hasil kali antara $\mathrm{P}_{1}$ dan $\mathrm{P}_{2}$. Padahal seharusnya volume tersebut dicari mengunakan rumus $\mathrm{V}=\mathrm{S}^{3}$ sehingga untuk kotak pertama di dapatkan $\mathrm{V}=14^{3}$ dan kotak kedua $\mathrm{V}=18^{3}$ setelah itu barulah dicari selisih antara kedua volume tersebut. Subjek AB juga tidak memeriksa kembali hasil pekerjaannya dan meyakini bahwa hasil kerja nya sudah benar. Selanjutnya, hasil kerja subjek AB untuk masalah 2 .

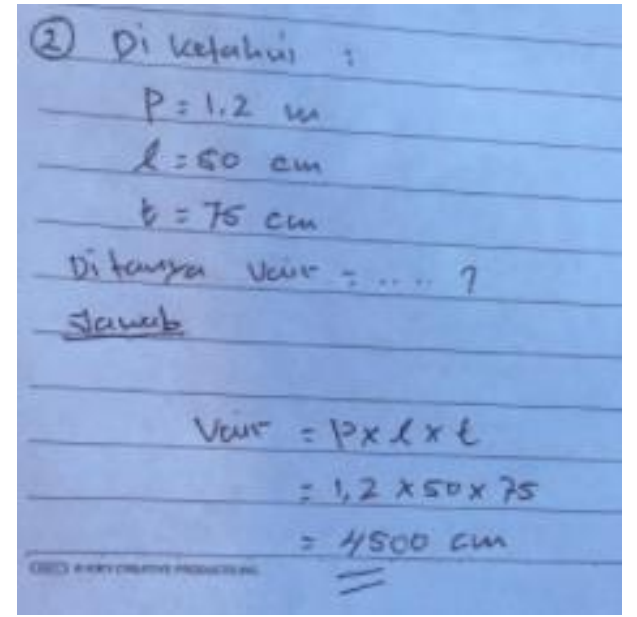

Gambar 6. Hasil kerja subjek AB untuk masalah 2

Berdasarkan hasil kerja subjek AB untuk masalah 2, didapatkan bahwa subjek AB tidak dapat memahami informasi dengan benar. Terlihat dari hasil kerja subjek AB bahwa subjek AB tidak menuliskan informasi terkait volume air dalam akuarium yaitu sebanyak 2/3 dari volume akuarium tersebut. Hal ini berdampak pada subjek AB tidak dapat menuliskan strategi yang benar sampai dengan menyelesaikan masalah trsebut dengan benar. Selanjutnya Subjek AB juga merasa ragu - ragu dengan jawabannya dan tidak memeriksa kembali jawaban tersebut.

Selanjutnya dilakukan wawancara dengan subjek $\mathrm{AB}$ untuk mengkonfirmasi kembali hasil kerja subjek AB untuk masalah 1 dan 2 .

$\mathrm{P} \quad$ : Selamat pagi dek.

$\mathrm{AB} \quad$ : Selamat pagi kak.

$\mathrm{P}$ : Mohon maaf mengganggu waktunya, Saya mau konfirmasi terkait dengan hasil pekerjaan dek untuk masalah 1 dan 2.

AB :Baik kak

P :Pada masalah 1, apa yang diketahui dan 
ditanyakan dari soal tersebut.

AB : Panjang sisi kotak pensil berbentuk kubus Endang dan Budi. $\mathrm{P}_{1}=14 \mathrm{~cm}$ dan $\mathrm{P}_{2}=18$ $\mathrm{cm}$. Selanjutnya yang ditanyakan yaitu volume dari kotak pensil tersebut.

$\mathrm{P} \quad$ : oiya baik. Sudah yakin dengan informasi dari soal tersebut? adik mau gunakan strategi apa?

AB : Iya kak kira kira begitu kak. Saya mencari volume dengan cara mengalikan kedua panjang sisi yang diketahui yaitu $\mathrm{V}=\mathrm{P}_{1} \mathrm{x}$ $\mathrm{P}_{2}$

$\mathrm{P} \quad$ : Kenapa strateginya seperti itu?

AB : Karena untuk mencari volume kita bisa mengalikan kedua sisi tersebut kak.

$\mathrm{P} \quad$ : apakah kamu yakin dengan strateginya? Apa tidak mau diperiksa lagi?

AB : Iya kak. saya rasa sudah benar kak. Kalau tidak salah cara kerjanya seperti itu kak.

P : Volume kotak pertama dan kedua, hasilnya sudah benar ya? $254 \mathrm{~cm}$

AB : Iya kak sudah benar

P : Oke baik. Apa satuannya sudah benar dek? Selanjutnya apa lagi yang perlu dicari dek?

AB : oiya kak sudah benar kak, satuannya $\mathrm{cm}$,karena yang diketahui panjang sisinya satuannya $\mathrm{cm}$ juga kaka. Saya rasa hasil kerjanya sudah pas kak.

P : Oiya baik dek. Bisa kita lanjutkan ke masalah kedua?

AB : Silahkan kak. Boleh kak.

$\mathrm{P}$ : Pada masalah kedua yang diketahui dan ditanyakan apa saja?

AB :Menurut saya diketahui Panjang, lebar dan tinggi akuarium.

P : Apa dek yakin yang diketahui Cuma itu saja? Trus strategi apa yang digunakan dalam mengerjakan masalah tersebut?

AB : Menurut saya pas kak, yang diketahui itu saja kak. Kita mencari volume air dalam akuarium dengan rumus $\mathrm{V}=p x l x t$.

$\mathrm{P} \quad$ :Oke baik. Saya melihat hasil kalinya yaitu $4500 \mathrm{~cm}$, apa sudah benar? Dan apa satuannya $\mathrm{cm}$ dek?

AB : Iya benar kak. Satuannya cm kak.

$\mathrm{P} \quad$ : oke baik. Apa tidak mau diperiksa lagi dek?

AB : Iya kak. Menurut saya sudah benar kak

P : Oke. Makasih ya dek. Saya rasa cukup dek.

AB : Baik kak. Sama sama kak.

Pada tahap memahami masalah, terlihat subjek AB tidak mampu memahami masalah dengan baik. Berdasarkan hasil pekerjaan tersebut, subjek AB tidak dapat menyebutkan hal - hal yang diketahui dan ditanyakan dengan benar. Hal ini memperlihatkan bahwa subjek berkemampuan rendah mengalami kesulitan dalam memahami masalah. Selanjutnya, pada tahap membuat perencanaan, subjek $\mathrm{AB}$ tidak dapat menentukan strategi yang digunakan untuk menyelesaikan masalah 1 dan masalah 2. Hal ini memperlihatkan subjek berkemampuan rendah mengalami kesulitan dalam membuat perencanaan masalah. Pada tahap melaksanakan rencana, subjek $\mathrm{AB}$ belum dapat melaksanakan rencana sesuai dengan perencanaan yang telah dibuat. Terlihat subjek AB dapat menyelesaikan masalah tersebut namun masih salah. Lebih lanjut, pada tahap memeriksa kembali, subjek AB mampu memeriksa kembali namun masih belum dapat memeriksa jawaban dengan benar dan melihat kesalahan pengerjaan soal pada tahap sebelumnya.

Berdasarkan hasil penelitian ditemukan bahwa siswa berkemampuan tinggi kesulitan dalam memeriksa kembali hasil penyelesaian masalah, siswa berkemampuan sedang mengalami kesulitan dalam menentukan strategi yang akan digunakan, menggunakan strategi tersebut untuk menyelesaikan masalah dan memeriksa kembali hasil penyelesaian masalah tersebut. Selanjutnya siswa berkemampuan rendah memiliki kesulitan mulai dari memahami masalah, menentukan strategi penyelesaian, menggunakan strategi rencana dan memeriksa kembali penyelesaian masalah matematika. Hal ini dikarenakan peserta didik kurang memahami konsep geometri, tidak terbiasa berlatih soal pemecahan masalah yang mengakibatkan siswa tidak memiliki strategi - strategi dalam menyelesaikan masalah matematika yang ditemui. Hal ini sejalan dengan temuan oleh Sholihah \& Afriansyah (2018) yang menyatakan bahwa kesulitan siswa menyelesaikan masalah geometri karena tidak memahami konsep prasyarat dan konsep geometri serta kurangnya keteranpilan menggunakan ide - ide geometri dalam menyelesaikan masalah geometri. Temuan lain oleh Mahdayani (2016) menyatakan bahwa factor lain siswa tidak dapat menyelesaikan masalah geometri dengan baik yaitu siswa tergesa - gesa dan kurang teliti. Lebih lanjut dikatakan oleh Nugraha et al. 
(2015) serta Tias \& Wutsqa (2015) menyatakan bahwa siswa juga sering lupa dengan strategi yang akan digunakan dan merasa terkecoh dengan hal-hal yang diketahui dari masalah tersebut.

Penelitian ini dapat menjadi bahan referensi bagi guru matematika untuk dapat memahami kesulitan siswa dalam menyelesaikan masalah matematika khususnya siswa SMP Negeri I Amanuban Barat.

\section{SIMPULAN DAN SARAN}

Berdasarkan uraian tersebut, dapat disimpulkan bahwa siswa berkemampuan tinggi kesulitan dalam memeriksa kembali hasil penyelesaian masalah, siswa berkemampuan sedang mengalami kesulitan dalam menentukan strategi yang akan digunakan, menggunakan strategi tersebut untuk menyelesaikan masalah dan memeriksa kembali hasil penyelesaian masalah tersebut. Selanjutnya siswa berkemampuan rendah memiliki kesulitan mulai dari memahami masalah, menentukan strategi penyelesaian, menggunakan strategi penyelesaian dan memeriksa kembali penyelesaian masalah matematika. Hal ini dikarenakan peserta didik kurang memahami konsep geometri, tidak terbiasa berlatih soal pemecahan masalah yang mengakibatkan siswa tidak memiliki strategi - strategi dalam menyelesaikan masalah matematika yang ditemui.

Selanjutnya, saran yang dapat diberikan yaitu guru perlu memetakan kesulitan menyelesaikan masalah pada setiap materi yang ada sehingga membantu guru dan siswa dalam mengatasi kesulitan menyelesaikan masalah matematika.

\section{DAFTAR PUSTAKA}

Ayubi, I. I. Al, Erwanurdin, \& Bernard, M. (2018). Pengaruh Pembelajaran Berbasis Masalah Terhadap Kemampuan Pemecahan Masalah Matematis Siswa Smp. JPMI (Jurnal Pembelajaran Matematika Inovatif), 1(3), 445. https://doi.org/10.22460/jpmi.v1i3.p445 $-452$

Hadi, S., \& Radiyatul, R. (2014). Metode Pemecahan Masalah Menurut Polya untuk Mengembangkan Kemampuan Siswa dalam Pemecahan Masalah Matematis di Sekolah Menengah Pertama. EDU-MAT: Jurnal Pendidikan Matematika, 2(1), 53-61. https://doi.org/10.20527/edumat.v2i1.6 03

Hertiavi, M., Langlang, H., \& Khanafiyah, S. 2010. Penerapan Model Pembelajaran Kooperatif Tipe Jigsaw untuk Peningkatan Kemampuan Pemecahan Masalah Siswa SMP. Pendidikan Fisika Indonesia, 6(1), 53-57. https://journal.unnes.ac.id/nju/index.ph p/JPFI/article/view/1104

Hidayat, W., \& Sariningsih, R. (2018). Kemampuan pemecahan masalah matematis dan adversity quotient siswa SMP melalui pembelajaran open ended. JNPM (Jurnal Nasional Pendidikan Matematika), 2(1), 109118. http://dx.doi.org/10.33603/jnpm.v2i1.1 027

Jamal, F. (2014). Analisis kesulitan belajar siswa dalam mata pelajaran matematika pada materi peluang kelas XI IPA SMA Muhammadiyah Meulaboh Johan Pahlawan. Jurnal MAJU (Jurnal Pendidikan Matematika), 1(1), 18-36. http://www.ejournal.stkipbbm.ac.id/ind ex.php/mtk/article/view/232

Mahdayani, R. (2016). Analisis kesulitan siswa dalam pemecahan masalah matematika pada materi aritmatika, aljabar, statistika, dan geometri. Jurnal Pendas Mahakam, 1(1), 86-98. http://103.8.79.252/index.php/pendasm ahakam/article/view/39

Mawaddah, S., \& Anisah, H. (2015). Kemampuan pemecahan masalah matematis siswa pada pembelajaran matematika dengan menggunakan model pembelajaran generatif (generative learning) di SMP. EDUMAT: Jurnal Pendidikan Matematika, 3(2). http://dx.doi.org/10.20527/edumat.v3i2. 644 
Mirati, L. (2015). Analisis Kesulitan Belajar Matematika Pada Topik Logika Pada Siswa SMK Muhammadiyah 3 Klaten Utara. MAJU: Jurnal Pendidikan Matematika, 2(2), 25-40. https://www.ejournal.stkipbbm.ac.id/in dex.php/mtk/article/view/109

Nasir, M. (2016). Efektivitas Model Pembelajaran Berbasis Masalah Problem Based Learning) Terhadap Kemampuan Pemecahan Masalah Siswa Pada Pelajaran Matematika. Madrasah Ibtidaiyah, 1(2), 1-19. https://ojs.uniska-

bjm.ac.id/index.php/jurnalmuallimuna/a rticle/view/381

Novferma, N. (2016). Analisis Kesulitan Dan Self-Efficacy Siswa Smp Dalam Pemecahan Masalah Matematika Berbentuk Soal Cerita. Jurnal Riset Pendidikan Matematika, 3(1), 76. https://doi.org/10.21831/jrpm.v3i1.104 03

Nugraha, N., Kadarisma, G., \& Setiawan, W. (2019). Analisis kesulitan belajar matematika materi bentuk aljabar pada siswa smp kelas vii. Journal On Education, 1(2), 323-334. https://jonedu.org/index.php/joe/article/ view/72

Purnamasari, I., \& Setiawan, W. (2019). Analisis Kemampuan Pemecahan Masalah Matematis Siswa SMP pada Materi SPLDV Ditinjau dari Kemampuan Awal Matematika. Journal of Medives: Journal of Mathematics Education IKIP
Veteran Semarang, 3(2), 207-215. https://doi.org/10.31331/medivesvetera n.v3i2.771

Sholihah, S. Z., \& Afriansyah, E. A. (2018). Analisis Kesulitan Siswa dalam Proses Pemecahan Masalah Geometri Berdasarkan Tahapan Berpikir Van Hiele. Mosharafa: Jurnal Pendidikan Matematika, 6(2), 287-298. https://doi.org/10.31980/mosharafa.v6i 2.317

Tias, A. A. W., \& Wutsqa, D. U. (2015). Analisis Kesulitan Siswa Sma Dalam Pemecahan Masalah Matematika Kelas Xii Ipa Di Kota Yogyakarta. Jurnal Riset Pendidikan Matematika, 2(1), 28. https://doi.org/10.21831/jrpm.v2i1.714 8

Utari, D. R., Wardana, M. Y. S., \& Damayani, A. T. (2019). Analisis Kesulitan Belajar Matematika dalam Menyelesaikan Soal Cerita. Jurnal Ilmiah Sekolah Dasar, 3(4), 534-540. http://dx.doi.org/10.23887/jisd.v3i4.223 11

Widjajanti, D. B. (2009, December). KEMAMPUAN PEMECAHAN MASALAH MATEMATIS MAHASISWA CALON GURU MATEMATIKA: APA dan BAGAIMANA MENGEMBANGKANNYA. In Seminar Nasional FMIPA UNY (p. 1). http://staffnew.uny.ac.id/upload/131569 335/penelitian/Makalah+5+Desember+ UNY+Jadi.pdf 